Discussion Paper No. 02-80

Competition in the

German Broadband Access Market

\author{
Margit A. Vanberg
}

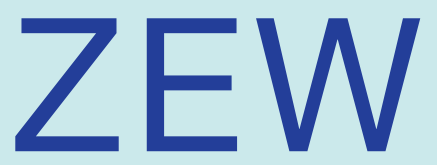

Zentrum für Europäische Wirtschaftsforschung GmbH

Centre for European

Economic Research 
Discussion Paper No. 02-80

\title{
Competition in the German Broadband Access Market
}

\author{
Margit A. Vanberg
}

Download this ZEW Discussion Paper from our ftp server:

ftp://ftp.zew.de/pub/zew-docs/dp/dp0280.pdf

Die Discussion Papers dienen einer möglichst schnellen Verbreitung von neueren Forschungsarbeiten des ZEW. Die Beiträge liegen in alleiniger Verantwortung der Autoren und stellen nicht notwendigerweise die Meinung des ZEW dar.

Discussion Papers are intended to make results of ZEW research promptly available to other economists in order to encourage discussion and suggestions for revisions. The authors are solely responsible for the contents which do not necessarily represent the opinion of the ZEW. 


\section{Non-Technical Summary}

According to recent studies on the international deployment of broadband Internet access services, German subscribership to high speed Internet access is below OECD average. Furthermore, broadband Internet access in Germany is almost to $100 \%$ based on DSL technology, provided on the infrastructure of the incumbent telecommunications carrier Deutsche Telekom (DT). In contrast, those countries showing the highest penetration rates of broadband Internet access, such as Korea, Canada, Sweden and USA, are all characterized by at least two independently owned and operated infrastructures for broadband Internet access services. This paper gives a survey of the German broadband access market and examines the role competition policy and regulation have played in its development.

The analysis shows that in Germany, technological alternatives to DSL, such as cable-modem, satellite and Powerline Communications, are evolving only very slowly and preferably in urban areas, where due to a higher population density, the large fixed costs of building and operating an independent infrastructure are divided among more customers. Given the geographical extension of the German cable-TV (CATV) network and the number of households subscribing to CATV services, cable-modem technology is the most promising candidate for facilities-based competition in the German broadband access market. The paper analyses the historical circumstances which have slowed the process of upgrading the German CATV network for two-way communication applications and concludes that consolidation in the German cable industry is a necessary prerequisite for a significant deployment of broadband Internet access capabilities on this infrastructure.

Without competition from independent infrastructures, the local loop of the incumbent telecommunications carrier DT remains a monopolistic bottleneck for the provisioning of broadband Internet access services. In the short to medium term, unbundling regulation is therefore necessary and justified as a means of furthering service-based competition by competitive local exchange carriers. Although Germany was one of the first countries requiring the unbundling of the local loop, competitive local exchange carriers have not been able to gain significant market shares with their respective DSL products. The paper calls for further strengthening of unbundling regulation. 


\title{
Competition in the German Broadband Access Market
}

\author{
MARGIT A. VANBERG \\ Centre for European Economic Research (ZEW), Mannheim
}

October 2002

\begin{abstract}
This paper gives a survey of the current state of competition in the German Broadband access market. Existing regulations and their impact on the deployment of high-speed Internet access are evaluated. It is argued that facilities-based competition is preferable to open-network regulations. The most prospective candidate as an independent network capable of generating facilities-based competition in Germany is the cable-broadcasting network. The current developments in the cable industry and the expectations for its success in the short to medium term lead to the conclusion that in the short run at least, there is a need for unbundling regulation to foster competition. Improvements to the current opennetwork regulation-practices in Germany are suggested.
\end{abstract}

Keywords: broadband access, local network competition, regulation JEL Classification: L43; L50; L96

Address: $\quad$ Centre for European Economic Research (ZEW)

Research Group Information and Communication Technologies

P.O.Box 103443

D-68034 Mannheim

Phone: $\quad+49 / 621 / 1235-351$

Fax: $\quad+49 / 621 / 1235-333$

E-Mail: vanberg@zew.de 


\section{Contents}

1 INTRODUCTION................................................................................. 1

2 INTERNATIONAL BROADBAND DEVELOPMENT.................... 2

3 THE GERMAN BROADBAND ACCESS MARKET....................... 6

3.1 DT's T-DSL ROLL-OUT............................................................

3.2 CLECS DSL OFFERS ............................................................. 10

3.3 CABLE MODEM .................................................................... 12

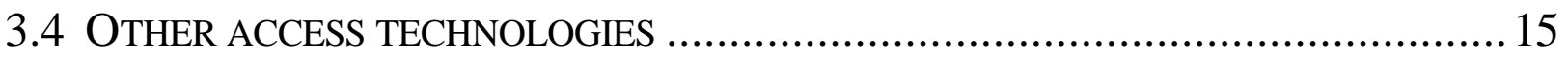

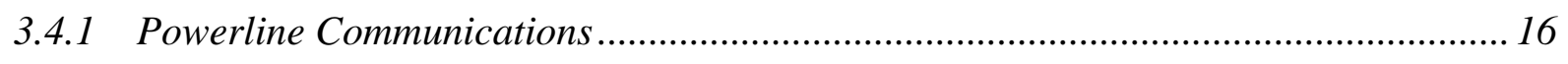

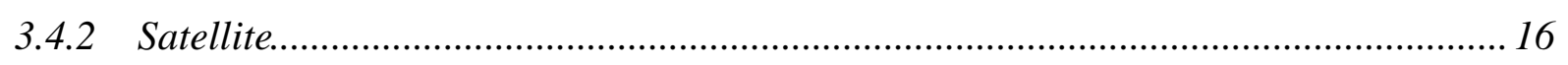

4 ACCESS-REGULATION............................................................................. 17

4.1 FACILITIES-BASED COMPETITION ............................................... 20

4.1.1 Incentives to Invest into Alternative Networks ......................................................... 20

4.1.2 Consolidation in the Cable Industry …................................................................... 22

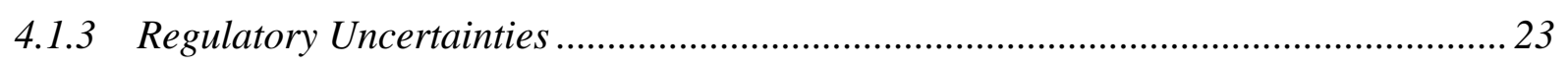

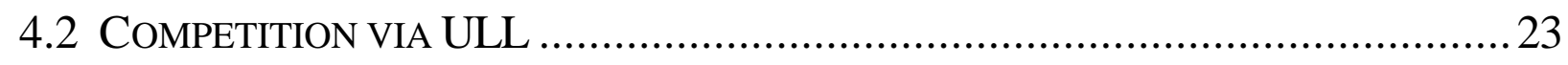

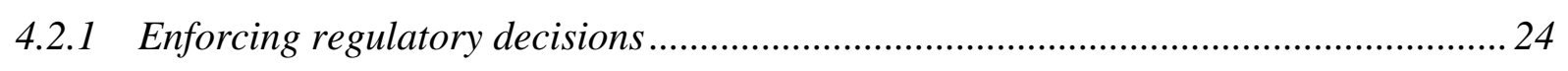

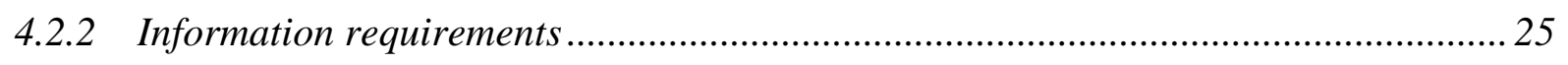

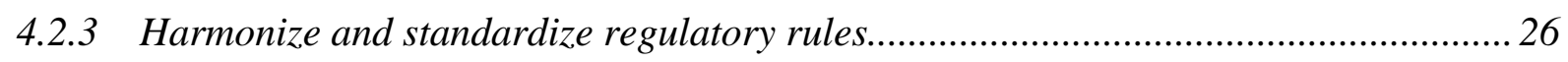

4.2.4 Political independence of regulatory authorities....................................................2

5 SUMMARY AND CONCLUSION .........................................................28

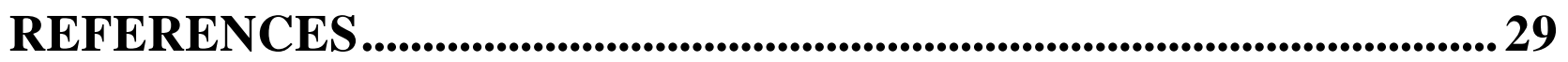




\section{Introduction}

The increasing employment of information technologies in the economy has lead to a heightened demand for advanced communication capabilities. Key technological progress has emerged in the field of broadband Internet access. ${ }^{1}$ Many new Internet services (e.g. online-games, video streaming, audio content in digital quality and video-conferences) already make use of the higher transfer speeds attained by new technologies. Naturally, their success depends on a wide deployment of broadband infrastructure among users. Thus, the innovative broadband technologies and broadband applications are adding a new aspect to the debate on local network competition. The crucial question is, whether the possibilities to get access to broadband Internet capabilities are keeping step with the applications developed for this medium. A recent OECD report states: "The current bottleneck to growth in the communications sector, and beyond for areas such as electronic commerce, is the limitations of local access networks."

In Germany telecommunications industry representatives and policy makers are debating the question whether the broadband Internet access offer of the German incumbent carrier Deutsche Telekom (DT) has enabled DT to monopolize not only the market for broadband Internet access but has actually resulted in a factual remonopolization of the local loop by DT. The alleged monopolization could hinder a quick deployment of broadband capabilities at competitive prices. Against the background of this discussion, this paper examines the current developments in high-speed Internet capabilities in Germany and the state of competition in this market. Furthermore, the paper evaluates existing regulations and their impact on broadband deployment, and discusses options for future broadband policy that may further competition in this market.

To provide a benchmark for assessing the broadband development in Germany, section 2 gives a short overview of the broadband-access development in other EU and OECD countries. In section 3 a survey of the current state of competition in the German broadband-access market follows. The focus will be on offers by independent network operators (facilities-based competition) as well as offers by competitors making use of unbundling or line-sharing agreements to access DT's existing network.

At this time, the only noteworthy competition in the German broadbandaccess market stems from new entrants relying on unbundling regulation of DT. However, the market share of the new entrants has been stagnating on a rather low level. The impact that past regulatory policy, especially unbundling and line-sharing regulation, has had on this problem is evaluated in section 4 . The insights attained

\footnotetext{
1 The term "broadband" is used in accordance with the OECD definition of broadband access. The OECD defines broadband as a downstream connection exceeding $256 \mathrm{Kbps}$ and an upstream connection of at least $64 \mathrm{Kbps}$ (OECD, 2001: 6). This allows the inclusion of the basic DSL offers of most DSL providers in OECD countries, which will typically be used by private consumers and small businesses.

2 OECD, 2001: 4.
} 
by the survey of the current developments in broadband competition shall finally be used to draw conclusions for future broadband policy. Section 5 concludes with a short summary. ${ }^{3}$

\section{International Broadband development}

There are two recent international studies providing insight into the development of broadband Internet access services. The first is a study conducted by the OECD $\left(\mathrm{OECD}\right.$ study $\left.{ }^{4}\right)$, which evaluates the penetration of high-speed Internet access in OECD member-states for data current in June 2001. In another study, commissioned by the European Commission and the EFTA Surveillance Authority (EU legal study ${ }^{5}$ ), the state of competition in local loop markets of EU member states is evaluated for data current in September 2001.

The OECD study reveals sizable differences between the broadband-access penetration in OECD countries. The average penetration of high-speed Internet access in OECD countries was at 1.96 persons in 100 inhabitants in June 2001. Korea had the highest penetration rate with 13.91 subscribers per 100 inhabitants, whereas some countries, such as the Slovak Republic, Turkey, Greece, Ireland and Mexico had virtually no subscribers to broadband Internet access at this time. In Germany 1.03 persons per 100 inhabitants had subscribed to broadband Internet access in June 2001. Broadband penetration in Germany was therefore below the OECD average at this time.

The study looks at the development of broadband-access offers in each of the OECD countries in terms of penetration and pricing behavior. The market shares of access providers, the existing regulations for open access, and the timing of offers to the public are evaluated. The OECD identifies competition between at least two independent network infrastructures as one key aspect in the development of broadband services. ${ }^{6}$ The hypothesis is, that the roll-out of broadband services on the network of the incumbent telecommunications carrier is faster the higher the competitive pressure from services provided over alternative infrastructures, such as cable modem. This theory is supported by the observation that those OECD countries showing a quicker deployment of broadband access, and the highest rates of penetration of broadband-access services, are all characterized by having at least two independent infrastructures on which high-speed Internet-offers are realized. Table 1 summarizes the OECD countries which had exceeded two high-speed

3 For the purposes of this paper it is assumed that competition in the market is welfare-improving. For a discussion of the welfare-effects of network-competition in telecommunications markets see Burr, 1995: sec. 2.2 .

4 OECD, 2001.

5 Squire Sanders, Legal Counsel Worldwide, 2002. The study is based on a questionnaire among new entrants in EU member-states, asking for information on remaining difficulties in obtaining access to the unbundled local loop, after the Regulation No 2887/2000 on unbundled access to the local loop became mandatory in all member-states as of January $01,2001$.

6 OECD, 2001: 9. 
Internet-subscribers per 100 inhabitants in June 2001, and the respective shares of DSL and cable modem services in these countries at this time. The numbers for Germany are added as a reference point.

Table 1. Broadband Penetration and Infrastructure Competition in June 2001

\begin{tabular}{|l|ccc|}
\hline & $\begin{array}{c}\text { Total Broadband } \\
\text { Penetration per 100 } \\
\text { Inhabitants }\end{array}$ & DSL share & $\begin{array}{c}\text { Cable } \\
\text { modem } \\
\text { share }\end{array}$ \\
\hline Korea & 13.91 & $65 \%$ & $35 \%$ \\
Canada & 6.22 & $37 \%$ & $63 \%$ \\
Sweden & 4.52 & $31 \%$ & $20 \%$ \\
USA & 3.24 & $38 \%$ & $62 \%$ \\
Netherlands & 2.74 & $22 \%$ & $78 \%$ \\
Austria & 2.36 & $36 \%$ & $64 \%$ \\
Denmark & 2.33 & $56 \%$ & $44 \%$ \\
Belgium & 2.27 & $40 \%$ & $60 \%$ \\
\hline Germany & 1.03 & $100 \%$ & $0 \%$ \\
\hline
\end{tabular}

Source: OECD, 2001 and own calculations

Except for Sweden and Denmark, all countries listed in Table 1 have in common that their largest telecommunications and cable networks are owned by independent operators. On both infrastructures broadband-access to the Internet is being offered, and both technologies attain sizable market shares. In Sweden, where Telia, the incumbent telecommunications carrier, also owns a large part of the cable infrastructure, competition from an independent infrastructure is provided by socalled "property networks" using fibre-optic Ethernet LAN (loacal area network) connections in apartment buildings. 50\% of the broadband-access subscribers in Sweden have subscribed to such "property networks". The OECD study argues that due to this competition, Telia roled out DSL on its telecommunications network at very attractive prices, which further encouraged a higher broadband-access penetration in Sweden. ${ }^{7}$ In Denmark, the incumbent telecommunications provider owns the largest cable company whereby the threat of competition from alternative infrastructures is reduced. However, the second largest cable company in Denmark is capable of supplying one fifth of all Danish households with high-speed Internet access and is exerting considerable competitive pressure on Tele Danmark. ${ }^{8}$

OECD, 2001: 40.

8 OECD, 2001: 25. Interesting in this context $\dot{\mathrm{B}}$, that this second largest cable operator is a subsidiary of the Swedish telecommunications incumbent Telia. While the Telia Daughter in Denmark sells its Internet access product to $23.9 \%$ of the Danish cable-TV subscribers, Telia's cable branch in Sweden has sold Internet access to only $2.8 \%$ of its cable-TV subscribers (OECD, 2001: 39). This supports the 
Further indication that competition between independent infrastructures fosters a quicker penetration of broadband-access is given by the cases of the Nordic countries Finland and Norway, where a higher penetration rate of broadband Internet access could have been expected, given the technological maturity in these countries with respect to Internet usage in general. According to the Global eCommerce Report 2001 Norway had the highest percentage in the adult population using the Internet in 2001 worldwide. Finland ranked third among the European countries in terms of Internet penetration. The degree of mobile phone usage may also be an indicator of the otherwise quick take-up of new technologies in these countries. Finland had the highest percentage of adults with access to a mobile phone in 2001 worldwide, with Norway ranking third in this statistic. ${ }^{9}$ With regards to the penetration of broadband Internet access, however, Finland and Norway rank $10^{\text {th }}$ and $14^{\text {th }}$ in the OECD area in June 2001. The OECD study attributes this to the fact that in both countries the incumbent telecommunications carrier owns a large share of the cable network, and that there is no other alternative infrastructure for broadband-access competing with the incumbents infrastructure.

A further stimulus to competition in the broadband-access market, according to the OECD study, is competitive pressure from telecommunications carriers using unbundling and line-sharing agreements to offer high-speed Internet access over the access network of the incumbent telecommunications carrier. Especially in areas where facilities-based competition has not yet unfurled and will not be economically viable in the short to medium term, the regulatory requirements for unbundling and line-sharing play a significant role in the development of service-based competition in broadband Internet access. The OECD concludes, "The evidence indicates, that opening access networks, and network elements, to competitive forces increases investment and the pace of development". ${ }^{10}$

While unbundling requirements for the local loop exist in almost all OECD countries, the progress in the implementation of unbundling policies varies widely across member-states. Some countries implemented local loop unbundling at or around the time of market liberalization in the EU, as for instance Germany (1 January 1998), Finland (June 1997), and Denmark (1 January 1998). Most countries, however, waited until the required implementation date of the EU Unbundling Regulation 2887/2000, the $1^{\text {st }}$ of January $2001 .{ }^{11}$ Many states register only a handful of unbundled lines, but even in those states with larger numbers of unbundled lines such as Germany (549 467), Denmark (40 000), Finland (40 000), and the

thesis that an operator owning two different infrastructures often will not have an interest in providing broadband services over both technologies.

9 The Global eCommerce Report is published by Taylor Nelson Sofres. It covers 36 countries and is based on interviews with 42,742 people conducted in the first half of 2001. Download at http://www.tnsofres.com/ger2001/home.cfm.

10 OECD, 2001: 4.

11 Squire Sanders, Legal Counsel Worldwide, 2002: 11. 
Netherlands (6 650) the numbers add up to only a small percentage of the total access lines in their respective countries. ${ }^{12}$

According to the EU Legal Study and the Seventh Report on the Implementation of the Telecommunications Regulatory Package by the EU (Commission of the European Communities,.2001, see Footnote 12) the advancement of line-sharing offers and whole-sale offers that were required in the regulatory package on unbundling in order to further competition especially with regards to broadband-access services has been even more unsuccessful than the advancement of basic offers for full-unbundling. ${ }^{13}$ At the end of October 2001, of the 13 European incumbents offering a high-speed Internet access on the retail level, only the Danish, Spanish, Italian, Austrian, Swedish, and British incumbent had a wholesale offer that has been taken up by competitors. ${ }^{14}$ Shared access was only operational in four of the member-states at the beginning of 2002. ${ }^{15}$ At this time in Germany, shared access was not even included in the Reference Unbundling Offer (RUO) of the incumbent. ${ }^{16}$

In order to understand the factors hindering a quicker development of servicebased competition (carriers using the infrastructure of the incumbent to access their customers), the EU legal study in September 2001 surveyed 250 competitive carriers on the regulatory and commercial framework for unbundling in their respective countries. The carriers were asked to report on any obstacles they encounter in the practical unbundling process. The study groups the reported hindrances into either "tariff and cost-related issues" or "behavioral obstacles".

Among the "tariff and cost-related issues" are alleged discriminations in price and quality for local loops and related services as compared to the terms offered to the incumbents retail service company. Competitors state that they are subjected to a price squeeze since retail prices of the incumbent are below the access costs competitors pay. ${ }^{17}$ In some countries even allegations of predatory pricing by the

12 Commission of the European Communities,.2001: 21. Number of access lines for Germany and Denmark current on September 30, 2001, for Finland on October 15, 2001, and for the Netherlands on October 31, 2001.

13 With the adoption of Regulation 2887/2000, the terms mandating shared access and wholesale offers of the incumbents retail services became mandatory for EU states as of January 01, 2001. These offers were mandated in order to permit the entrance of Internet service providers not wishing to also supply the customers voice services.

14 Commission of the European Communities, 2001: 20.

15 Shared access was operational in Belgium, Netherlands, Finland, and Sweden. Squire Sanders, Legal Counsel Worldwide, 2002: 4 and Commission of the European Communities, 2001: 21.

16 Squire Sanders, Legal Counsel Worldwide, 2002: 11

17 The European Commission has recently sent DT a statement of objection arguing that DT is abusing its dominant position by charging competitors higher prices for the access to its local loop than what DT's subscribers pay for retail access (Commission Press release IP/02/686 from May 08, 2002). This is a difficult political issue because historically the subsidization of residential access and local services by long-distance services was a political obligation to the monopolist. The commission is of the view that the market liberalization requires a re-balancing of the retail rates since subsidization is not sustainable in a competitive market. 
incumbent have been the issue of proceedings before the national competition and regulatory authorities. ${ }^{18}$

The reported "behavioral obstacles" include unjustifiable delays in the implementation of mandated services, delays in the delivery of lines and collocation, discriminatory provisioning terms, and discriminatory product quality as compared to the incumbents own retail service arm. ${ }^{19}$ The alleged hindrances would suffice to render a legally available unbundling offer, whose prices may not even be discriminatory, not practicable. The EU legal study records "damaging economic results of varying seriousness" as a result of the hindrances new entrants face. ${ }^{20}$

The observation that the practical implementation of unbundling regulations is made difficult by various hindrances explains the fact that competition between providers of broadband-access to the Internet is observed mainly where independent facilities-based competitors have entered the market. Where no significant share of services is based on independent networks, as in Germany, the incumbent has succeeded in seizing first-mover advantages in the market for broadband Internet access. In Germany, this tendency has raised the fear that DT may be remonopolizing the local loop through its dominant position in the broadband access market. The next section looks more closely at the actual developments in the German broadband-access market.

\section{The German broadband-access market}

By the end of 2001, 5 percent of German households had high-speed Internet access. Of these households, 98.4 percent subscribed to a form of DSL service. Other technologies, such as cable modem, Powerline and Satellite, have played no significant role in Germany thus far. An overview of the distribution of the 2.1 million subscribers to high-speed Internet access is given in Table 2.

Table 2. Subscribership by Technology (End of 2001)

\begin{tabular}{|l|cc|}
\hline & $\#$ & Percent \\
\hline T-DSL DTAG & 2 Mio. & $95.1 \%$ \\
xDSL Competitors & 70,000 & $3.3 \%$ \\
Cable-modem & 30,000 & $1.4 \%$ \\
Powerline & 2,000 & $0.1 \%$ \\
Satellite & NA & NA \\
\hline
\end{tabular}

Source: RegTP report for 2001, p. 15.

The numbers show the clear dominance of the incumbent carrier in the broadband-access market: 95.1 percent of broadband subscribers use "T-DSL", DT's

18 Squire Sanders, Legal Counsel Worldwide, 2002: 17.

19 Squire Sanders, Legal Counsel Worldwide, 2002: 18.

20 Squire Sanders, Legal Counsel Worldwide, 2002: 56 ff. 
broadband-access product. Only 3.3 percent subscribe to a DSL product of a competitive local exchange carrier (CLEC). ${ }^{21}$ Given that Germany was one of the first countries requiring the unbundling of the local loop, and especially given that unbundling was already implemented before DSL retail offers were presented by either the incumbent or CLECs, the small market share of the CLECs is surprising. At least in larger urban areas, those end-users upgrading to broadband Internet access had a choice between T-DSL and competing CLEC offers at the time of their decision to subscribe to broadband Internet access service. Broadband Internet access providers have however been only marginally more successful in gaining customers than CLECs in the local market for voice telephony. ${ }^{22}$

The market shares given in Table 2 also show that infrastructure competition among alternative broadband-access networks is not pronounced in Germany. The highest potential for facilities-based competition is accredited to the already existing infrastructure for Cable Television. The currently small cable modem market share of only 1.4 percent at the end of 2001 is explained by the fact that DT historically owned both the telecommunications infrastructure and the cable infrastructure. Because a large part of the cable infrastructure today still remains in the possession of DT, and since DT naturally has no incentive to develop broadband Internetservices on both of its network infrastructures, the realization of the competitive potential of the cable infrastructure depends on the sale of DT's cable network.

The evolvement of the German broadband Internet access market, as depicted by the market shares in Table 2 , is contrary to the development many economists had predicted. It had been expected that the demand for broadband capabilities could better be met by cable modem or WLL technologies than by the conventional copper loop, and that the demand for new broadband applications would therefore be a stepping stone for alternative technologies in the local loop. ${ }^{23}$ The predicted success of the alternative technologies was even expected to be so great as to allow a reduction in the regulation in the local loop in a not so far future. ${ }^{24}$ Clearly, the current market shares tell a different story. For a better understanding of the structure of the German broadband-access market it is worthwhile to give a short overview of how this market evolved. The following subsections will therefore

${ }^{21}$ Of the German CLECs most use the unbundled local loop to access their customers. CLECs have invested in independently built and operated local access infrastructure mainly only in new property developments in urban areas, where no previous infrastructure exists. According to the RegTP 80 percent of the access lines operated by CLECs at the end of 2001 were rented local loops. (RegTP, 2001b: 14).

22 Possibly the low CLEC market shares in broadband Internet access are strongly related to the low market shares of CLECs in the market for local voice telephony. Since line-sharing was not available until April 2002, CLECs were forced to rent the full unbundled local loop and offer a bundle of voice and data services. The requirement to also switch their voice carrier when choosing an alternative DSL provider may have kept customers from subscribing to a competitors product.

23 Gabelmann and Gros, 2000: 116.

24 Merkt, 1998: 101, Wichert-Nick, 1999: 87, and Kruse, 2001: 85. 
focus on the economic, technological, and regulatory forces that have shaped this market.

\subsection{DT's T-DSL roll-out}

Since the transmission of DSL signals is realized on the given decades-old copper telephone lines connecting nearly every household, a local access provider has comparatively small roll-out costs for DSL-services. The upgrade of the network consists mainly of installing a DSL access multiplexer (DSLAM) in the central office switch wherever DSL is to be offered, and installing splitters at each end of the local loop to separate the high frequency band for data transportation from the low frequency band where voice data are transported.

DT launched T-DSL in $1999 .{ }^{25}$ By now it is potentially available to $90 \%$ of German households. ${ }^{26}$ The restriction stems from the fact that current technology allows the DSL signals to be carried over no more than $4 \mathrm{~km}$ to the switch. Longer distances between the home and the first switch lead to attenuation problems, such that DSL-access is problematic in low-density rural areas where the length of the local loop can exceed the required length. A further reason for the restriction in the DSL-availability is the deployment of optical fiber rings in so called "OPAL regions". In the course of upgrading the local access copper network, DT moved the optical fiber closer to the end-user - in these regions the copper pairs do not connect to the central office switch but are rather multiplexed closer to the end-user, making DSL unbundling at the central office collocation impossible. In these OPAL regions, and wherever the length of the local loop exceeds $4 \mathrm{~km}$, T-DSL is currently not being offered. ${ }^{27}$

In Germany, broadband-access via DSL grew at a fast pace. DT followed a penetration price strategy, entering the market with very low prices. In 2000 for instance, DT offered T-DSL in connection with T-ISDN voice service at a special promotional price of DM $14,89(€ 7,61)$ per month. This price was guaranteed until December 2002 for orders placed before the end of December 2000. Since, starting in 2001, this service would be priced at DM 19,90 (£ 10,18), this offer was clearly aimed at a quick market penetration. ${ }^{28}$ At the same time, DT's online service provider T-Online offered flat-rate Internet access to T-DSL customers for only DM 49 ( $€ 25)$ per month. The combination of ISDN, T-DSL, and the T-Online flatrate for T-DSL thus became less expensive than ISDN service alone with the regular T-

25 By the end of 1999 T-DSL was available in 58 cities (DT Press release "T-DSL auf der Cebit 2000", February 24, 2000).

26 c't 7/2002 "Anschluss-Wahl: DSL. Kabelmodem, Satellit, Powerline - Optionen für den schnellen Internet-Zugang": 133.

27 DT has recently stated that its T-DSL roll-out is now on hold. Customers in rural areas, where no T-DSL is available, are referred to DT's broadband Internet access product via satellite access. See Handelsblatt August 1, 2002, "Telekom bremst den DSL-Ausbau".

${ }^{28}$ DT press release August 17, 2000, "Deutschl@ nd geht online mit T-DSL". 
Online flatrate of DM $79(€ 40,40)$ per month. ${ }^{29}$ As a result of these special prices, DT attracted more T-DSL orders than she could fulfill. Yet, DT did not turn down customers, but rather concluded the contracts, even though the wait for a DSL connection came to be over 6 months in 2000. ${ }^{30}$ In March 2001, for instance, DT reported 850.000 T-DSL customers of which only 400.000 were actually connected. ${ }^{31}$

It was speculated that DT - knowing that it would have to divest itself of its cable infrastructure - wanted to get a head start on the cable competition, and therefore had a strong interest in a dumping-price strategy. ${ }^{32}$ CLECs argued that they could not match the DT conditions without incurring losses and requested that the German regulatory authority (RegTP), examine the T-DSL charges in an ex-post regulatory review. ${ }^{33}$ The RegTP opened proceedings against DT on February $2^{\text {nd }}$, 2001. DT's supporting documents argued that the T-DSL prices were calculated according to economies of scale accessible with the mass-market strategy that DT was pursuing. On the $30^{\text {th }}$ of March 2001 RegTP concluded that the T-DSL prices were not sufficient to cover the current costs of the service. However, RegTP ruled in favor of DT's prices, arguing that losses at the time of a product launch are normal, and that DT has to be allowed the time to reach a critical mass where lower acquisition prices will ultimately make the pricing strategy profitable. ${ }^{34}$ RegTP further argued that a fast deployment of broadband-access capabilities at attractive prices was in the interest of the German public.

RegTP thought this decision justified because it considered a dumpingstrategy by DT highly implausible. RegTP argued that for a dumping strategy to be effective, DT would have to cover losses incurred in the dumping-period by raising prices above the competitive level in a subsequent period. ${ }^{35}$ This however would assume that DT would be able to deter entry in that second period. RegTP claimed that regulatory oversight would however hinder DT from undertaking any anticompetitive entry deterrence practices. Therefore higher prices in a second period would result in customers switching away from DT to competitors' products.

Furthermore, RegTP argued that competitors' concerns on their competitiveness were also accounted for in concurrent decisions taken by RegTP with regard to the rent for the fully unbundled local loop and the newly mandated possibility to rent only the high-frequency band of the local loop (line-sharing). These decisions were geared towards lowering input prices for competitors and

\footnotetext{
29 c't 19/2000 “Mit Vollgas sparen: Die Telekom drückt T-DSL mit Dumping-Preisen in den Markt”.

30 See supra note 29.

31 DT press release March 20, 2001, "T-DSL: Netzausbau der Deutschen Telekom läuft auf hohen Touren".

32 See supra note 29.

33 c't 4/2001 'Schnell Surfen soll teurer werden - Telekom Konkurrenten: Der T-DSL-Anschluss ist zu billig".

${ }^{34}$ RegTP, Decision BK 3b-00/032: 45.

35 This is also known as the ,proof of recoupment“, see Bolton et al., 2000: 2255.
} 
establishing a level-playing field. ${ }^{36}$ According to RegTP these decisions would allow competitors to compete with DT's prices. Lastly, RegTP emphasized that DT had been obliged to improve its service-quality, especially with regards to delays in the provisioning of collocation space, leased lines, and local loops.

When by the end of 2001 no significant improvement in the entry conditions for competitors (see next sub-section) had taken place, RegTP threatened to reopen the proceedings on the T-DSL prices. Because of this threat, DT in February 2002 raised T-DSL monthly rates by 25 to 30 percent. The one-off installation fee was increased in two steps by almost 100 percent. ${ }^{37}$ The price-increase has had no effect on DT's market share. ${ }^{38}$ RegTP has declared itself satisfied with these prices and sees no need for further action at this time. ${ }^{39}$

\subsection{CLECs DSL offers}

About 23 CLECs have DSL offers for residential customers. ${ }^{40}$ Most rent the unbundled local loop (ULL) from DT and offer both voice-telephony and data access to end-users. Besides renting the full ULL CLECs, since April 2002, also have the option of renting only the high-frequency band of the ULL to provide Internet access services while voice services are continued by the local exchange carrier (line-sharing). There are no statistics available on the up-take of this new offer.

Transfer-speeds of CLECs are comparable to those offered by DT in the retail market. Prices are at or below DT's price-level. The greatest disadvantage of CLEC DSL-offers is their limited availability. CLEC offers are generally restricted to the more attractive urban areas. These areas are more attractive because the large set-up costs for operating a collocation-site is divided among a higher number of households connected to this site. The initial provisioning of the site, the provisioning of the leased-line linking the collocation-site with the CLECs backbone, and the acquisition costs for switching equipment signify large fixed costs per collocation-site for an alternative carrier. As a switch in a remote area serves fewer customers, CLECs cannot amortize the one-off costs in rural areas with the market shares they expect to obtain there.

CLECs have therefore concentrated their roll-out on larger German cities. In June 2002 the web-pages of the largest alternative national carrier Arcor stated that Arcor's DSL services are available in over 100 cities. The web-pages of national carrier QSC's stated that OSC's DSL-product is available in almost 50 German

${ }^{36}$ RegTP, Decisions BK 3c-00/029 and BK 4a-01/001/E.19.01.2001. See also RegTP, 2001b: 103.

37 DT Press release January 15, 2002, "Deutsche Telekom legt Regulierer neue T-DSL Preise vor".

38 This is interesting, as some tests of predation require that prices rise within a reasonable time. See: Baumol, 1979.

39 RegTP, Press release from January 22, 2002, "T-DSL Verfahren wird eingestellt."

40 RegTP, 2001b: 15. RegTP reports 23 A-DSL offers. Since S-DSL offers are generally not oriented towards residential customers, I do not count S-DSL providers here. The number also does not include resale offers. 
cities. According to RegTP, CLEC's orders to DT for the provisioning of new collocation sites have, however, decreased drastically since January $2001 .^{41}$ This is an indication that the roll-out efforts of CLECs have come to a halt - at least for the time being.

CLECs in Germany complain of the same tariff- and cost-related obstacles and behavioral obstacles to market entry as entrants in other EU countries (see section 2). Especially the fact that DT's retail price for basic access service is below the rental price for the unbundled local loop is a continuing point at issue between DT and the CLECs. Since most DSL carriers also offer voice services and require that a customer switch completely to the CLECs service bundle, the price-squeeze in the market for basic access also effects the DSL carriers. Besides claims of price squeezing, many CLECs complain of delays allegedly caused by DT in the unbundling process. CLECs state that the time-consuming negotiation process and the complicated ordering process for inputs, as well as the delays in the delivery of collocation spaces and access lines has obstructed their market entry. Furthermore, CLECs criticize, that DT's LLU standard offer lacks contractual penalties for these delays. ${ }^{42}$

The criticisms brought forward by CLECs can perhaps best be exemplified by an account of the course of events surrounding the line-sharing negotiations in 2001: At the same time DT was pushing its DSL product on the downstream market, it delayed offering and implementing intermediate services for competitors, to which she had been obliged by rulings of the European Commission and the RegTP. The regulatory decisions on line-sharing aimed at furthering competition in the broadband-access market by providing equal access to the upstream bottleneck facilities. While the terms of the EU directive $2887 / 2000^{43}$ became mandatory among EU member states as of 1 January 2001, DT awaited the outcome of national regulatory proceedings on the EU directive. In March 2001 a RegTP decision obliged DT to make a non-discriminatory offer for shared access by $30^{\text {th }}$ of May 2001 and to negotiate and test the final offer by September 2001. In May, DT filed an appeal against this decision with the next higher court. Both the VG Köln (in June) and the OVG Düsseldorf (in August) confirmed the initial RegTP Decision. ${ }^{44}$

Only after having taken all possible legal steps did DT finally offer a linesharing contract in August 2001. Since DT's offer contained conditions not acceptable to its competitors, and especially because DT requested higher prices for line-sharing than had been regulated for the full unbundled local loop, commercial start was not immediately possible. RegTP did not intervene to settle the disputed terms and conditions, because it interprets the German Telecommunications Law as

\footnotetext{
${ }^{41}$ RegTP, Decision BK3e-02/002: 28.

42 Squire Sanders, Legal Counsel Worldwide, 2002: $123 \mathrm{ff}$. A recent regulatory decision (from July 01, 2002) on the LLU contract has obliged DT to include contractual penalties for delays in the delivery of unbundled local loops and collocation spaces by August 1, 2002 (see BK3e-02/002).

43 Squire Sanders, Legal Counsel Worldwide, 2002: 6 and12.

${ }^{44}$ RegTP, 2001: p.107 and Monopolkommission, 2001: 81.
} 
requiring contract negotiations between the incumbent operator and its competitors before particular terms and conditions of a negotiated contract can be subject of a regulatory proceeding. ${ }^{45}$

Negotiations on DT's offer began in September. The competitive DSL-carrier QSC finally signed DT's contract offer in December $2001 .{ }^{46}$ The negotiated terms were then presented to the RegTP, which announced its decision on the line-sharing price on the $18^{\text {th }}$ of March 2002. Therefore, by first delaying the implementation of the EU directive and the decisions by the RegTP, and by an outdrawn negotiation and regulatory process, DT had at least an extra 15 months for a successful early roll-out of its T-DSL retail services, before competitors had access to line-sharing. Because of this delay, Germany was among the last member-states in the European Union to fulfill the terms on shared unbundled access mandated by the EU. Furthermore, DT has not put forward DSL-specific wholesale offers, and competitors continue to be obstructed by disputes and delays in the unbundling process for the fully unbundled local loop.

Apart from the fact that through its early roll-out and attractive prices, DT was able to seize a first-mover-advantage in the market for broadband Internet access services, DT now also has a technical first-mover-advantage over competitors entering the market at a later time: Because only a limited percentage of the copper lines in one bundle can be upgraded for DSL services before interference sets in, DT has a legitimate technical reason to refuse unbundling the local loop for DSLservices once this percentage is reached.

Although the delay between the initial regulatory requirement and the implementation of the mandated service may have been especially long in the case illustrated here, the method of delaying regulatory decisions in the manner described is no exception but rather the rule. The account of the regulatory process leading to a line-sharing offer can therefore be taken as an example of the behavioral obstacles to entering the market that CLECs complain of.

\subsection{Cable modem}

The coaxial cable network, originally built for Cable-TV access, can also be used to transport IP-signals to the user. Substantial investments are necessary to make the existing cable-TV network capable of two-way traffic, as generated by Internet access-services. These investments are, however, less than the investments necessary to build an altogether new network. Therefore, the cable-TV network, which passes by almost 70 percent of German households, has the chance of

\footnotetext{
45 "The RegTP takes the view that market participants are best placed to assess the extent to which terms and conditions offered by DTAG are burdensome and unacceptable, rather than the RegTP reviewing and approving an agreement up-front as a reference offer." Squire Sanders, Legal Counsel Worldwide, 2002: 123 .

46 QSC Press Release December 20, 2001.
} 
becoming a nation-wide independent alternative infrastructure for broadband Internet access services. ${ }^{47}$

A distinctive feature of the German cable infrastructure is its fragmentation into independently owned and operated cable franchises. The infrastructure is split into 4 different network levels. Level 1 comprises the production of TV-and RadioProgramming. Level 2 contains the transmission from production sites to receptionstations in the networks of level 3 operators. Level 3 is the actual backbone network of coaxial cable that extends to the customer premises. Level 4 encompasses the last meters from the curb to the cable outlet in the customers house/apartment.

DT formerly held 80 percent of level 3 and around 30 percent of level 4 infrastructure. ${ }^{48}$ Because the $\mathrm{EU}$ was considering legislation demanding the institutional separation of the cable and telecommunications business of former monopolies, DT in 1998 established a holding company for its cable activities. ${ }^{49}$ Of the 9 Cable Regions in the holding, DT sold three by the end of 2001. The cable infrastructure of the Bundesländer Nordrhein-Westfalen (NRW) and BadenWürttemberg (BW) were purchased to 55 percent and 45 percent by Callahan Associates International LLC, that operate under the company name "ish" in Germany. The cable infrastructure in Hessen now belongs to 65 percent to a consortium around Klesch \& Company, a London-based private equity firm. The company name for the Klesch products is "iesy". The remaining shares continue in the possession of DT, however, the investors have the option to obtain the DT shares. The conflict of interest for DT concerning the success of the cable operators in voice-telephony and Internet access is obvious. Therefore it is to be hoped that DT sells the remaining shares sooner rather than later.

Callahan and Klesch each also purchased the cable-TV business and customers of the Deutsche Telekom level 4 operator DeTeKabelService GmbH. Callahan therefore has direct customer access to 1 Mio. of the 4.2 Mio. households in NRW and 900,000 of 2.2 Mio. in BW. Klesch owns the level 4 infrastructure for 450,000 of 1.3 Mio. Cable-TV households in Hessen. ${ }^{50}$ While iesy so far offers broadband Internet access in some parts of Frankfurt only, ish began upgrading its network to a two-way network, capable of supporting high-speed Internet services and voice-telephony access on a larger scale. More recently, investments have come to a halt, however, as Callahan NRW, the parent company of ish, had to file for bankruptcy in July 2002. ${ }^{51}$ Ish's "triple-play-strategy" of providing users with voice-telephony, data and TV-services has not had the hoped-for success. It is

47 According to statistics on the homepage of ANGA - the association of private cable-TV operators http://www.anga.de/deutsch/statistik/statistik.html.

48 According to Anga statistics, see supra note 47.

49 On the $16^{\text {th }}$ of December 1997 the EU published a preliminary version of a new "Cable Directive", that was in favor of a structural separation of cable- and telecommunications networks (Wichert-Nick, 1999: 180).

50 According to the cable-operators organization Anga, cited in the Frankfurter Allgemeine Zeitung from March 04, 2002, p. 18, "Immer mehr Kabelnetzempfänger wechseln zur Satellitenschüssel”.

${ }^{51}$ Frankfurter Allgemeine Zeitung, July 22, 2002, p.15. 
currently uncertain if the future business plan will include the continuation of the upgrading of the network for Internet access services.

\section{Figure 1. Structure of TV-Reception in Germany}

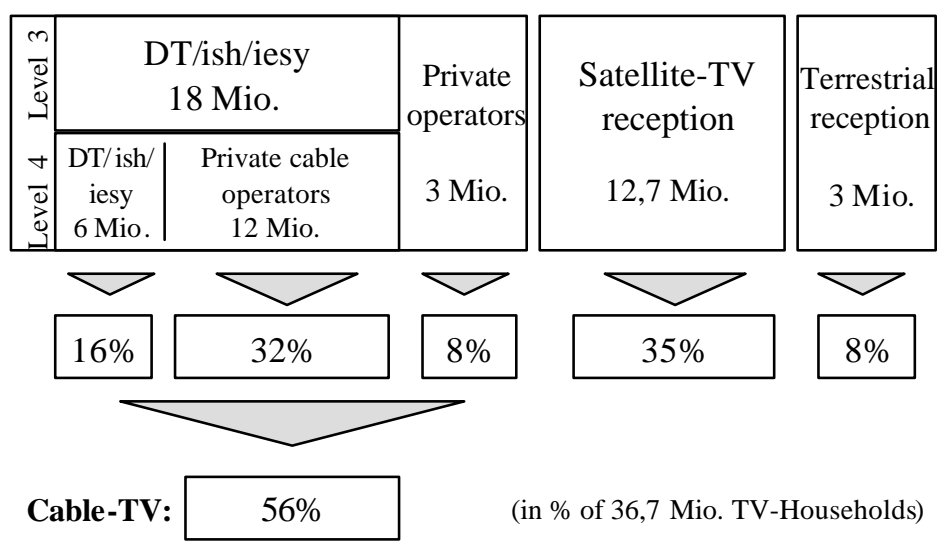

Source: ANGA Verband Privater Kabelnetzbetreiber e.V.

In order to provide Internet access and voice telephony, the level 3 operator is dependent on the cooperation of level 4 operators. According to the RegTP, there are about 5000 private level 4 operators in Germany. ${ }^{52}$ As a result, the negotiations with level 4 operators are a further difficulty on top of the cost of upgrading level 3 networks. Recently these negotiations have suffered from the fact that the Federal Cartel Office did not consent to the purchase of DT's remaining 6 cable-regions by Liberty Media. Liberty Media had intended to consolidate the levels 3 and 4 in the regions it wanted to purchase. The Federal Cartel Office did not consent to the acquisition because it feared that Liberty Media would obtain a dominant position in the market for Cable-TV access by consolidating the levels 3 and 4 . The president of the Cartel Office had announced that the purchase could be permitted only under the condition that Liberty provide for more competition in the neighboring markets for local voice-telephony and Internet access. Liberty, however, had not been willing to accept any obligations concerning the timing of its entry into the markets for voicetelephony and Internet access. ${ }^{53}$

Because the Liberty deal did not materialize, the uncertainty in the cable-TV market has increased, and level 4 operators are increasingly unwilling to commit to investments in the upgrading of their networks. Since the level 4 is a bottleneck for

\footnotetext{
52 RegTP, 2001a:19.

53 Handelsblatt, January 28, 2002, "Kartellamt will Liberty die Kabelnetz-Übernahme verbieten”.
} 
level 3 operators, this tie-up is affecting the business strategy of newcomers ish and iesy. The uncertainty in the market is further evidenced by the fact that after the failed Liberty deal no firm has shown a serious interest in purchasing any or all of the remaining 6 DT cable regions. Competition from independent cable-TV providers is consequently very slim at the moment, and it remains highly uncertain how many cable-TV customers will be able to subscribe to cable-based Internet and telephone services in the future.

Prices for the existing broadband Internet access offers via cable modem are comparable to those for DSL-services. While transfer speeds attainable via cable modem can reach far higher rates than currently provided via DSL, these transfer speeds are not guaranteed, because cable is a shared medium, meaning that the transfer speed is divided among those users connected at the same Cable Head Station. ${ }^{54}$ The transmission delay for signals uploaded to the Internet and the time for the reaction to reach the user is longer, the more subscribers are online at the same time. The longer transmission delay with broadband Internet access via cable modem is a disadvantage of this technology as compared to DSL, especially for online-gaming and for voice over IP applications.

The current developments show that (1) it is still uncertain whether all or most of the cable-TV network will be upgraded for data and voice transmission; (2) even if the entire cable network were upgraded, its maximum coverage would be 70 percent of German households; and (3) cable modem access is not a perfect substitute to DSL for all broadband applications. However, the potential for cable can be seen in the development in other countries. There is a risk, that because of the decision by the Federal Cartel Office, not to authorize the purchase of DT's remaining cable regions by Liberty Media, Germany has missed the chance of cablebased competition in broadband Internet access on a widespread scale. The longer the upgrading of the cable network is put off, the greater the first-mover advantage for DSL will be, and the less likely it becomes that cable will be established as the second network infrastructure capable of offering Internet access and telephone services.

\subsection{Other access technologies}

Experience in other countries has shown that the cable modem has so far been the most successful alternative technology in the local access market (see section 2). However, since regional distinctions can favor a particular technology in one country that may not be successful in another country, this overview of the German broadband Internet access market should at least mention the other technologies

54 Typical transfer speeds offered in the German retail market via DSL technology are download-speeds of $786 \mathrm{Kbit} / \mathrm{s}$ and upload-speeds of $128 \mathrm{Kbit} / \mathrm{s}$. Cable modem users can count on attaining roughly the same speeds. 
currently playing a role in the German broadband Internet access market for residential users. ${ }^{55}$

\subsubsection{Powerline Communications}

Powerline Communications (PLC) is a method of transferring data signals over the electricity network. PLC was paid a lot of attention in its beginnings as a possible widespread alternative to local loop unbundling. Since the coverage of the electricity network is 100 percent PLC technology has the potential to become a widespread alternative to the traditional telecommunications infrastructure. The transfer speeds attainable are currently about $2 \mathrm{Mbit} / \mathrm{s}$ per transformation station. As with the cable modem, PLC is a shared medium, and the available capacity is shared among all households connected to a transformer station (200 households on average).

However, due to technical difficulties and regulatory uncertainties many companies have already given up their PLC test-projects. ${ }^{56}$ The uncertainties surrounding PLC result from the concern that data transmission over unshielded power cables can cause interference with wireless applications such as public broadcasting, emergency broadcast services, and amateur radio. Since PLC is restricted to those frequencies not interfering with security-relevant frequencies, the available spectrum is narrowed by these other uses. On behalf of the European Commission, ETSI (European Telecommunications Standards Institute) is currently working on a standardized norm for interference thresholds. Due to differing interests in the member-countries, the adoption of a European norm will however probably take at least several more years. ${ }^{57}$ Due to this uncertainty, investments into PLC are risky, and many operators are waiting for a clearer regulatory framework before pursuing their projects further. It is rumored that RWE, considered to be the most promising candidate for a wide-spread PLC deployment in Germany, is about to surrender its plans of offering broadband services over the electricity network. ${ }^{58}$ This shows that the future of PLC in Germany is more uncertain now than it had seemed a couple of years ago.

\subsubsection{Satellite}

Broadband-access via satellite has the advantage that it can reach a nationwide coverage. It is especially interesting for rural areas, where wireline broadband technologies are either too expensive to install (cable modem) or do not work because of long distances between customer premises and the first switching office (DSL). Because of the restrictions of DSL and cable modem in rural areas, satellite

\footnotetext{
55 There are of course more broadband access technologies, such as WLL and Ethernet-LANs . Since they have not played a role in the German market for residential users, they will not be considered here. The prospective of UMTS is also too uncertain to be considered at this time.

56 Höckels, 2001: 76.

${ }^{57}$ Conversations with representatives of the RegTP and the BMWI (Federal Ministry of Economics and Technology).

58 c’t 12/2002 "RWE will Powerline Projekt loswerden".
} 
could be the only option for broadband Internet access in some regions. Satellite technology may also profit from the fact that it is already widely accepted for the reception of TV signals.

There are however several disadvantages to this technology. Firstly, satellite reception requires large investment in equipment on the part of the end-user (satellite dish and PC-adapter cost more than $€ 1000$ ). ${ }^{59}$ Secondly, the installation of the equipment involves a far greater effort than, for instance, the installation of DSL. Also, the monthly charges for broadband access via satellite are currently higher than for DSL and there exists no low-priced Internet access flat-rate for satellite access. Furthermore, the quality of satellite broadband access is not comparable to wireline services. This is the case because transmission delays from the distance the radio signals travel to the satellite and back, make this technology unsuited to realtime applications such as online gaming or voice over IP. Lastly, restrictions in the quality of the access can result from trees or rain obstructing the line of sight between the end-users satellite dish and the satellite in orbit.

At least at the current price-level, satellite access cannot be considered an economical substitute for DSL access. This and the other drawbacks make satellite access interesting only for locations where other access technologies are not available. The potential of satellite technology to restrict the market power of DT is therefore limited.

\section{Access-Regulation}

Based on the description of the current state of the broadband-access market in section 3, this section will look at the role of competition policy and regulation in the advancement of broadband capabilities in Germany. The worldwide liberalization of telecommunication markets, which started in the 1970s, can be explained by lobbying pressure from potential entrants using new, cost-efficient technologies, and wanting to enter the market for long-distance voice-telephony. In addition, liberalization was facilitated by a new awareness among economists, that public utility industries, once considered natural monopolies, are rather the sum of smaller vertically integrated markets, of which many can sustain competition, and only some may remain monopolistic bottlenecks. From this view on public utilities resulted a new approach to the regulation of the telecommunications market. In many countries legal entry barriers to the market were abolished, and price and quality regulation of the former monopolist was supplanted or complemented by open-network regulation. Open-network regulation seeks to control the market power of the incumbent firm which may have the ability to hinder the emergence of competition in potentially competitive markets through its control over remaining

59 See for instance Tiscali's "Internet via satellite" at http://www.tiscali.de/main/Internet/satellite/ index.html. Tiscali offers satellite Internet access with a direct interactive return path. Offers by DTAG and Strato require an additional Internet access service for the upstream path. These hardware required for these offers is less expensive but the user faces extra costs for the upstream Internet access. 
monopolistic bottlenecks. The objective of open-network regulation is therefore to facilitate equal access to monopolistic bottlenecks in order to allow for competition on horizontally and vertically related markets. ${ }^{60}$

The American antitrust law provides a rationale for regulating monopolistic bottlenecks in the form of the "essential facilities doctrine" ${ }^{61}$ When a dominant firm controls an essential facility and denies access to competitors, this is considered a restraint of trade which justifies antitrust action. Since the 1996 amendment the German competition policy law, the Gesetz gegen Wettbewerbsbeschränkungen (GWB), also includes the concept of the "essential facility" ( $\$ 19$ Section 4, Sentence 4 GWB). Furthermore, the German telecommunications law (TKG) considers the denial of access to an essential facility by a dominant firm a misuse of market power ( $\$ 33$ TKG). Policy interventions by the federal cartel office and regulatory interventions by the RegTP in the telecommunications market can therefore be justified when a dominant firm abuses its control over a bottleneck facility to impede the evolvement of competition in related markets.

According to the disaggregated regulatory approach ${ }^{62}$, which seeks to supplant global regulation of dominant firms by disaggregated regulation of the localized source of market power, monopolistic bottlenecks are defined as network elements that (1) are indispensable for providing a service; (2) can only be obtained by the incumbent provider; and (3) cannot be duplicated in an economically feasible way. ${ }^{63}$ Of the preconditions for a monopolistic bottleneck, the one hardest to test for is whether the duplication of a particular network element is economically feasible. Theoretically, the demand conditions in the market under consideration as well as the extent of economies of scale and scope as well as potential sunk costs in this market will determine if a duplication of the network element is feasible.

When economies of scale are exhausted, more than one provider can own and operate the required network element at optimal scale. Then the network element can be duplicated even if sunk costs are involved. A case in point is the backboneinfrastructure of telecommunications networks which has been duplicated more than once. If economies of scale are relevant, however, then duplication of the bottleneck network element will only result if the necessary investments for entering the market are not sunk but are re-deployable to other uses upon exit of the market. In this case, if an incumbent is not operating efficiently, a competitor would profit from entering the market and offering the service below the incumbent's price and exiting again, should the incumbent react with more efficient operation after entry. In summary, sunk costs in combination with economies of scale substantiate monopolistic bottlenecks. ${ }^{64}$

60 Picot and Burr, 1996: section 3.3.2.

61 United States v. Terminal Railroad Association 224 U.S. 383 (1912), cited in Hohmann, 2001.

${ }^{62}$ For an overview of the disaggregated regulatory approach see Knieps, 2000.

63 Knieps, 2001: 2.

${ }^{64}$ It is beyond the scope of this paper to go deeper into the contestable markets theory (Baumol et al, 1988) which is the basis of the disaggregated regulatory approach. Central to this theory is that it looks not 
Viewing the broadband Internet access market in light of this theory, can help answer the question whether regulatory intervention in the market for broadband Internet access is justified. Offering broadband Internet access services requires a physical connection between an IP-Backbone and the end-users terminal equipment. Several CLECs have their own backbone infrastructure. Most, however, rent DT's local loop to bridge the "last mile" between their backbone and the end-users equipment. The local loop may therefore constitute a monopolistic bottleneck in the market for broadband Internet access services.

The question whether the local loop is a monopolistic bottleneck is also discussed in the context of whether competition in the market for local voice telephony is possible. Although the problem seems to be the same at first glance, there is a difference due to the fact that technical standards for either broadband services or voice-telephony can exclude the applicability of specific access technologies for one service, while they may be a source of competition for the other service (e.g. narrowband mobile services can be a substitute for narrowband wireline services such as voice telephony, but not for broadband-access services).

As shown in section 3, the copper local loop of DT is to date the only physical network capable of supporting broadband Internet access in most geographic areas of Germany. Alternative infrastructures supporting broadband Internet access services exist in only few urban locations. This is the case because the local telecommunications infrastructure is still characterized by a high level of fixed costs, especially due to the large costs associated with laying the cable into the ground. The high fixed costs make the existence of economies of scale likely. Furthermore, these costs are for the largest part non-reversible. Bypass activities by alternative carriers have therefore focused only on lucrative high-volume business customers. In the market for private users new infrastructure has mainly been build only in new development areas.

The observation that market entry has only taken place selectively strengthens the supposition that the economies of scale in local loop infrastructure are not exhausted. A duplication of the telecommunications infrastructure in the local loop

only at the conditions for market entry but also at the conditions of market exit. Potential competition can supplant active competition when (1) entry investments are reversible, that is, when exit is costless; (2) entrants have access to the same productive technologies at s ame costs as incumbent firms; and (3) entrants take the incumbent's prices as given and attract the entire market demand by offering at a lower price. The restrictive assumptions of the contestable markets theory have made the application of this model to policy issues controversial (see Shepard, 1984). The assumptions are also not fulfilled for the present case of broadband Internet access market: for instance, due to substantial product differentiation between the DSL providers, price differences cannot be considered the sole reason for demand to shift. And even if customers would switch to the provider with the most attractive prices, capacity constraints would hinder an entrant from serving the entire market, since market entry takes a substantial amount of lead time (negotiation of contracts, installing equipment, collocation spaces). The contestable markets theory is idealized and not many actual markets can be considered highly contestable. It's contribution to policy must however be seen in the clear analysis of hindrances to competition - be it entry barriers or exit barriers - which is useful to policy makers studying industry structures when considering market interventions (see Baumol et al., 1988: Chap. 17). 
therefore seems highly unlikely. It is more reasonable to expect that alternative access to the end-user may evolve over already existing infrastructures in parallel markets. Upgrading the cable or electricity networks for data transmission, for instance, involves significantly less sunk investments than the complete duplication of DT's local infrastructure. Based on the description of the alternative access technologies in section 3, section 4.1 analyzes which regulatory measures increase the chances for successful entry by alternative technologies. In the case that facilities-based entry is not likely to lead to substantial competition in the short to medium term, competition in the broadband access market will depend on unbundling regulation. Section 4.2 therefore analyzes the role of open-network regulation (unbundling regulation) in the German broadband Internet access market.

\subsection{Facilities-based competition}

When the cost of providing broadband Internet access via an alternative network is less than or equal to the incumbent's cost of providing broadband Internet access services, then facilities-based entrants can offer differentiated services at equal or lower cost and thereby increase consumer welfare. Furthermore, facilities-based competition offers incentives for innovation and cost-minimization in the market. It is especially because of this latter aspect that facilities-based competition is preferable to service-based competition from a welfare-perspective. Service-based competition is only viable with regulatory intervention in the market. Not only is regulation costly in itself, but for regulation to offer the right incentives for innovation and cost-minimization, the regulator would need perfect information on efficient technologies, on cost functions and on demand conditions in the market. ${ }^{65}$ Because the regulator will however be constricted to only imperfect information, service-based competition can only lead to second-best results.

The first priority of competition policy should therefore be to enable facilitiesbased competition to unfold wherever economically efficient. With regards to the market for broadband Internet access services, policy makers should, in a first step, concentrate on identifying the barriers to entry in the "last-mile segment" of the telecommunications market. In a second step, the possibilities of lowering the identified entry barriers need to be examined. The description of the development of alternative access technologies in section 3 provides valuable insights into this question.

\subsubsection{Incentives to Invest into Alternative Networks}

The large investments necessary to build or upgrade a network capable of supporting broadband Internet access services may be a barrier to enter into this market. These

65 Laffont and Tirole (Laffont and Tirole, 2002: 131) argue that facilities-based entry “...may be desirable even if the entrants enjoy no cost advantage over the incumbent and produce a close substitute on the competitive segment." They reason that a regulator gains more from the information provided by such yardstick competition than the welfare loss from inefficient network duplication. 
necessary investment costs are likely to fall over time as technological advances lead to cheaper hardware components. When deciding on the timing of their market entry, potential competitors will therefore weigh up the advantages of an early entry into the market with the cost-savings attainable by a later upgrading of their infrastructure. This was the case with Liberty Media that did not want to accept an obligation by the German federal cartel office to enter the market for voicetelephony according to a predefined time schedule in exchange for the permission to purchase the remaining DT cable regions (see section 3.3).

Because the timing of facilities-based market entry of competitors is dependent on the cost of the alternative technology, it is important, that retail rates and the conditions for unbundling send the right signals about when entry into the market is economically efficient. Incentives for efficient market entry are given by retail rates and access prices that reflect the cost of using the incumbent's network. ${ }^{66}$ This is the case because an entrant with higher costs of production will not duplicate the incumbents network when the market retail rates are not sufficient to cover its costs. The entrant will then share the incumbents network at rates reflecting the incumbents costs and compete in the retail market on a level-playing field. Only when the entrants costs of production are below the incumbents costs, will facilitiesbased entry become a profitable option. Retail price regulation in this case needs to make sure that efficient market entry is not impeded by cross-subsidization by the incumbent.

To hinder cross-subsidization by the incumbent, retail price regulation needs to implement a price-floor defined by the average incremental costs of the service in question. Furthermore, product bundles should cover their joint incremental costs and the entire product portfolio should cover the firm-specific common costs. ${ }^{67}$ These rules will insure that single products or product bundles are not subsidized by other products or product bundles and that the product portfolio does not contain predatory prices. Retail prices consistent with these rules will allow market entry into market segments whenever an entrant can provide a single product or a combination of products at lower production costs than the incumbent.

When the RegTP evaluated DT's T-DSL prices in the beginning of 2001 (see section 3.1) she found that at least some of the T-DSL products were priced below their average incremental costs. ${ }^{68}$ Since the DSL-decision allowed DT to continue

66 See also Armstrong, 2002: sec. 2.4.1.

${ }^{67}$ In a multi-product environment joint costs and common costs cannot be directly attributed to a specific product. Rather, the distribution of joint incremental costs and common costs according to administrative rules can lead to an inefficient allocation of resources. Therefore, the distribution of joint incremental costs and common costs should result from the market process. This can result in a product not contributing to the common costs. But as long as a product can cover its incremental costs, its production is efficient. (See also Faulhaber, 1975).

68 The RegTP considered T-DSL an incremental product to the supply of basic telephony capabilities. Using this definition, RegTP calculated the price floor of the T-DSL products by considering only TDSL specific incremental costs and no costs of the access line. While RegTP added a 9 percent mark-up for common costs (RegTP BK 3b-00/032: 39), the discussion of the remaining cost components 
the below-cost prices, the principle that retail rates should not take away incentives for facilities-based entry was violated. It is possible that the low T-DSL rates contributed to the slow entry of facilities-based competitors in Germany.

Because retail rates for data services are not subject to ex-ante regulatory scrutiny, DT had an incentive to shift costs to regulated products where a rate of return is guaranteed (i.e. inputs for competitors), and compete with low prices in the unregulated market, thereby signaling low production costs and deterring entry by competitors. ${ }^{69}$ The proceedings on the T-DSL prices have shown that ex-post regulatory control is subject to more political pressures than ex-ante regulation. This is the case because ex-post proceedings always question a status-quo, and therefore affect the established interests of consumers and firms, whereas ex-ante regulation only questions hypothetical prices and hypothetical interests. As long as competition in the market for broadband Internet access services is dependent on the access to the incumbent's network, and as long as DT has the possibility to finance below-cost prices by high margins in markets where she has significant market power, the prices for DT's broadband Internet access services should be subjected to ex-ante regulatory control.

\subsubsection{Consolidation in the Cable Industry}

The description of the present efforts by cable companies wanting to enter the German market for broadband Internet access has shown that the fragmentation of the cable network levels 3 and 4 is a further barrier to entry. Upgrading the existing coaxial cable to make it capable of supporting two-way Internet data traffic requires coordinating the efforts of the operators of all infrastructure levels. Furthermore, once the network is upgraded and Internet access services are offered to end-users, operators of the levels 3 and 4 need to negotiate interconnection rates for originating and terminating data traffic. At minimum, the coordination and negotiation between the separate infrastructure levels raise the cost of entering the market. In the worst case no settlement is reached and broadband Internet access offers via cable-modem are delayed.

Consolidation of the levels 3 and 4 could save the time and resources allotted to negotiations and thereby accelerate the deployment of broadband Internet access capabilities on the cable network. Because this is the case, it is difficult to comprehend the objection of the German federal cartel office to the consolidation intended by Liberty Media. The federal cartel office argued that a consolidation would strengthen Liberty Media's market power and in essence reduce the product variety available to end-users. The relevant competition from the point of view of the end-user is however not the competition between independent level 4 operators

strengthens the supposition, that the T-DSL prices would also have been below a price floor calculated only with incremental costs. This is so, because DT did not offer cost calculations based on the current costs of service but rather used stylized costs of an efficient process not yet realized by DT but largely accepted by RegTP.

69 See Bolton et al., 2000: 2299 for signaling strategies in predatory pricing. 
active in different regions but rather the competition between their regional cable$\mathrm{TV}$-provider and alternative broadcasters available to them, as, for instance, satellite-TV-broadcasters. What's more, the new Digital Video BroadcastingTerrestrial (DVB-T) technology might soon compete with the traditional TVbroadcasting technologies. The consolidation of the levels 3 and 4 would not take away a user's free choice to switch to a different broadcasting technology. Because the competition between cable-TV reception and satellite-reception is strong, the federal cartel office should value the possibilities from a consolidation in the cable market higher and revise its stance towards consolidation efforts in the future.

\subsubsection{Regulatory Uncertainties}

A further barrier to entry for cable operators into the Internet access market may result from regulatory uncertainties surrounding engagements in this market. By extending their business activities into the market for data transmission services which are classified as telecommunication services, cable operators become subject to the sector-specific telecommunications law (the TKG). The TKG allows the expost regulatory control of the retail rates for data services of dominant carriers. The uncertainty with respect to the Internet access market results from the fact that it is unclear how the RegTP will define the relevant market for Internet access services provided over cable. In its March 2001 decision regarding the T-DSL rates RegTP did not consider Internet access via cable modem to be in the same relevant market as DSL services. ${ }^{70}$ If in the reverse case RegTP would not consider DSL an alternative to broadband Internet via cable modem, but instead adopt a narrow definition of the relevant cable market, then practically every cable operator could become a dominant carrier with respect to his end-users. ${ }^{71}$ To reduce the regulatory uncertainty and enhance the planning reliability for operators of cable infrastructure, the regulatory framework should make clear that the relevant market for broadband Internet access services encompasses both DSL services and cable modem services.

Regulatory uncertainties are also a barrier to entry with respect to the PLC technology. Investments into PLC have at least in part come to a halt because of the uncertainties regarding the frequencies open to PLC providers. To reduce the uncertainty for potential PLC operators and to allow them to plan their investment strategy, the European commission should adopt a binding time plan for the implementation of a frequency standard.

\subsection{Competition via ULL}

The overview of the German broadband Internet access market in section 3 has shown that for the time being competition by facilities-based operators is confined to very few geographic areas and that no alternative infrastructure is currently capable

\footnotetext{
70 RegTP, Decision BK 3b-00/032: 29.

71 Möschel, 2001: 18.
} 
of competing with DT on a nation-wide basis. In the short term widespread competition in the market for broadband Internet access can therefore only come from CLECs renting the unbundled local loop. Because the local loop constitutes a bottleneck facility for these service-based competitors, unbundling regulation is justified.

Although Germany was one of the first countries requiring the unbundling of the incumbents network elements, the small market share of the service-based competitors in the market for broadband Internet access services can be taken as an indication that regulation has not been successful in providing a "level playing field". The description of the DSL roll-out by CLECs in section 3.2 points to weak spots in the German regulatory policy and suggests regulatory reforms that would strengthen the competition in the market.

\subsubsection{Enforcing regulatory decisions}

Even when the regulator takes a decision that aims at providing equal access to monopolistic bottlenecks, DT strategically prolongs the implementation of that decision. There are two critical factors that allow DT's retardation strategy. The first is the regulator's view on the primacy of negotiations before regulatory intervention: Although the motivation for requiring negotiations before regulatory intervention is to maintain a lighter-handed regulation, the effect has been that DT has no incentive to conclude negotiations in a timely manner. Since delays are only costly to competitors DT has no incentive to resolve disputes concerning its contractual offers. Rather, the higher the number of disputed contract items, the more likely it is that not every issue will be subject of regulatory screening, and will therefore remain in the Standard Offer.

The only way for competitors to speed up the regulatory process is to agree on DT's terms early and hope that the regulator will resolve many of the actually disputed items in subsequent regulatory proceedings. A case in point is that QSC, after having signed a line-sharing agreement on the $18^{\text {th }}$ of December 2001, filed for proceedings on the misuse of market power by DT in this same agreement on the $15^{\text {th }}$ of February 2002. ${ }^{72}$

To expedite the regulatory process the RegTP should issue decisions which already include regulations concerning recurring issues. ${ }^{73}$ This would spare the time devoted to negotiating the same items that had been cleared in a previous regulatory decision. Furthermore, the decision should specify a short time frame in which DT is obliged to negotiate further issues with competitors, and finally the decision should already specify the date for the final review by the RegTP, and the deadline for the submission of written comment by the parties involved. This way the delays from outdrawn negotiations can be averted.

72 QSC press release, February 15, 2002.

73 DT regularly cancels entire contracts and offers contracts contradicting earlier regulatory decisions. 
The second factor leading to a substantial delay in the implementation of regulatory decisions is that DT files suit against almost every decision taken by the RegTP. That DT does not implement decisions until all suits are resolved is illegal under $\$ 80$, Sec. 2 TKG. The RegTP has the right to enforce regulatory decisions through imposing an administrative fine of up to $€ 500,000$ (\$96 Sec.1, No.7 TKG in combination with $\S 96$, Sec. 2 TKG). However, although DT regularly delays the implementation of decisions, RegTP has not made use of this possibility of compulsory enforcement. ${ }^{74}$ The prolongation of the regulatory process is therefore also ascribable to a weakness of the RegTP. It is necessary that the RegTP make use of this right to enforce its decisions. ${ }^{75}$

\subsubsection{Information requirements}

In order to take regulatory decisions the RegTP is highly dependent on information provided by DT on its costs, on internal processes etc. According to RegTP decisions the information submitted by DT is often either not verifiable or incomplete. However, DT does not seem to bear any consequences from providing too little information. For instance, in its decision on the T-DSL prices RegTP explicitly allows a cross subsidization between T-DSL in combination with basic analogue services to T-DSL in combination with ISDN. However, RegTP did not have any information on the distribution of T-DSL customers between both products, and could therefore only make an assumption as to the actual degree of cost recovery from these products. Although the effort to DT of providing the information about the distribution of the T-DSL customers between analogue and ISDN service cannot have been prohibitively high, RegTP waived this information requirement. ${ }^{76}$

To increase the public's confidence in regulatory decisions, RegTP should enforce information claims more diligently in the future. The information rights of regulatory authorities have recently been strengthened by Article 11 of Directive 2002/19/EC of the European Parliament on the access to, and interconnection of, electronic communications networks and associated facilities (Access Directive). The article states that "a national regulatory Authority may, in accordance with the provisions of Article $8^{77}$, impose obligations for accounting separation in relation to specified activities related to interconnection and/or access."

74 The only instance I am aware of where the RegTP threatened to impose an administrative fine was in the proceeding concerning resale of local services (RegTP, BK 3b-01/019). Here the RegTP threatened to impose a fine of DM 2,000 should DT not implement the decision as mandated. It is obvious that a fine of this dimension is not threatening to an incumbent telecommunications carrier that has a lot to loose from an opening of the market.

75 The fact that the RegTP is hesitant in the compulsory enforcement of its decisions may also be a result of political dependencies (see section 4.2.3).

76 RegTP, BK 3b-00/032: 46.

77 Article 8 refers especially to operators designated as having significant market power on a specific market as a result of a market analysis carried out in accordance with Article 16 of Directive 2002/21/EC. 
In rate-regulation proceedings RegTP often resolves information deficits by resorting to benchmark prices from comparable services in other countries. However, with quality issues the dependency on the information of the incumbent is more difficult to resolve. Without structural separation between the infrastructure operation and the retail arm of the incumbent, it is difficult to observe which service conditions the incumbent offers to its own service arm, and the regulator therefore often lacks the evidence for discriminatory behavior. The regulator is dependent on statistical data provided by the incumbent, as for instance data on delivery times for local loops, on the number of open orders, on unbundled lines reported dysfunctional by CLECs, etc. Because empirical verification of the information given by the incumbent is costly, the probability that the incumbent submits false information is not negligible. One possibility to improve the quality of the data provided is to make more of the information transparent to competitive carriers. Since competitive carriers are directly affected by the quality of the incumbents' services, they will often be in a position which allows them to falsify false statements by the incumbent. To reach a higher degree of transparency, the requirements for information to be declared business secrets should be more stringent. Furthermore, giving false information should result in consequences.

\subsubsection{Harmonize and standardize regulatory rules}

In the decision on DT's DSL retail rates, the regulatory authority did not include costs of the local loop in the costs of DSL services (see sec. 4.1.1). RegTP argued that the costs of the local loop are covered by the monthly rental fee for telecommunication services and that therefore no "access deficit" (returns on access services minus costs of providing access) exists. This claim is contrary to RegTP statements in rate proceedings for the unbundled local loop. Here the fact that the ULL rental fee is higher than the retail monthly rental fee for basic analogue telecommunications service is explained with the argument that the costs of the local loop are common to all services using the local infrastructure, and that DT covers the "access deficit" in part by retail rates for voice-telephony. ${ }^{78}$

If the costs of the local loop are considered common costs to the services using the local infrastructure, it can be economically efficient that DT cover these common costs only with voice services and that data services cover only their incremental costs (see footnote 67). The regulation of DT's retail rates (and of interconnection charges to competitive carriers) should then, however, control that the access-deficit is covered by these services. However, neither the regulation of DT's retail rates for voice telephony nor the regulation of the interconnection charges to competitive carriers currently controls that the access deficit is actually covered. Therefore it is not clear from rate regulation proceedings if the access deficit is covered at all.

${ }^{78}$ Reg TP, BK 4e-98-024/E 21.09.1998: 38. 
The different standards currently applied in rate regulation proceedings, open the possibility for predatory pricing by DT, and leave CLECs with difficulties in recovering their access deficit (returns on access services minus the rental rate for the ULL and the costs of CLEC local infrastructure). In data services CLECs compete with DT's T-DSL product which is calculated at incremental costs. They can therefore only recover part of the access deficit with DSL products if they are more efficient than DT. In voice-services CLECs compete with long distance carriers that use DT's local infrastructure at interconnection charges that do not include a mark-up for the access deficit.

That different standards are applied in different regulatory proceedings increases the regulatory uncertainty in the market. Regulatory decisions should be consistent with each other. One solution to the inconsistencies in the treatment of the access deficit in regulatory proceedings is to raise the monthly retail fee to cover the costs of the local infrastructure. As long as high monthly retail fees continue to be considered politically infeasible, however, the only way to allow CLECS to cover the access deficit engendered by a higher ULL rental fee than fixed monthly retail charges is by making mark-ups on voice services possible. For this, it is necessary to explicitly control that DT also covers the access deficit and that interconnection charges for long distance carriers also include a mark-up for the access-deficit. ${ }^{79}$ In order not to burden CLEC's twice, once by the higher rent for the local loop and then in the interconnection charges for terminating calls on DT's network, the markup on interconnection rates should be levied on call origination charges only.

\subsubsection{Political independence of regulatory authorities}

The foregoing discussion has shown that many of the weaknesses in the German regulation have to do with a lack of assertion on the part of the regulator. This may be explained in part by excessive demand for regulatory action. An important factor will also be the political dependency of the regulatory agency. Although the RegTP is allegedly an independent institution, it nevertheless faces strong political interests in the regulatory treatment of DT, as the government is still the largest shareholder of DT. To increase the independence from administration representatives, policy measures need to be taken that reduce the likelihood of regulatory capture by government officials.$^{80}$ For instance, RegTP officials should be barred from taking a political position after their term of office expires.

\footnotetext{
79 See Armstrong, 2002: 19. Armstrong introduces a "correction factor" to the cost of access as a "secondbest output tax to correct for the fact that the incumbent's retail tariff does not reflect its costs." See also Laffont and Tirole (2000), sec. 3.2.2.

${ }^{80}$ See Laffont and Tirole, 2000: 59.
} 


\section{Summary and Conclusion}

The foregoing analysis has shown that in the German broadband access market facilities-based competition is evolving very slowly and preferably in urban areas, where due to a higher population density, the large fixed costs of facilities-based market entry are divided among more customers. Furthermore, it was shown that the uncertainties surrounding the prospects of the presented alternative technologies are not yet resolved. This paper concludes that in the short to medium term the local loop of the incumbent carrier remains a monopolistic bottleneck for the provisioning of broadband Internet access services, a fact that justifies, even calls for further strengthening of unbundling regulation. The analysis closes with recommendations for changes in the current regulatory framework which would strengthen the deployment of broadband access services by service-based competitors.

The analysis also raises a question for future research. If facilities-based entry will be successful in restricted geographical areas, should regulatory measures differentiate between geographical markets within Germany? Up until now, DT's retail prices do not differentiate among geographical areas. Similarly, rates for unbundled network elements are also oriented on geographical averages. The increased competition from facilities-based carriers may, however, require the deaveraging of retail rates and consequently also of the rates for intermediate services. Such measures would mean a complete re-organization of the existing regulatory framework. 


\section{References}

Armstrong, M. (2002), The Theory of Access Pricing and Interconnection, in:

Cave, M., S. Majumdar and I. Vogelsang (Eds.), Handbook of

Telecommunications Economics, New York.

Baumol, W. (1979), Quasi-permanence of Price Reductions: A Policy for

Prevention of Predatory Pricing, Yale Law Journal 89, 1-26.

Baumol, W., J. Panzar and R. Willig (1988), Contestable Markets and the Theory

of Industry Structure, New York.

Bolton, P., J. Brodley and M. Riordan (2000), Predatory Pricing: Strategic Theory and Legal Policy, The Georgetown Law Journal 88, 2239-2330.

Burr, W. (1995), Netzwettbewerb in der Telekommunikation: Chancen und Risiken aus Sicht der ökonomischen Theorie, Wiesbaden.

Commission of the European Communities (2001), Seventh Report on the Implementation of the Telecommunications Regulatory Package, Brussels.

Faulhaber, G. (1975), Cross-Subsidization: Pricing in Public Enterprises, The American Economic Review 65/5, 966-977.

Gabelmann A. and W. Gross (2000), Telekommunikation: Wettbewerb in einem dynamischen Markt, in: Knieps, G. and G. Brunekreeft (Eds.), Zwischen Regulierung und Wettbewerb-Netzsektoren in Deutschland, Heidelberg.

Höckels, A. (2001), Internationaler Vergleich der Wettbewerbsentwicklung im Local Loop, WIK Diskussionsbeiträge 228, Bad Honnef.

Hohmann, H. (2001), Die essential facility doctrine im Recht der Wettbewerbsbeschränkungen, Baden-Baden.

Kruse, J (2001), Regulierungsbedarf in der deutschen Telekommunikation?, in Immenga, U., C. Kirchner, G. Knieps, J. Kruse (Eds.), Telekommunikation im Wettbewerb. Eine ordnungspolitische Konzeption nach erfolgreicher Marktöffnung, München

Knieps, G. (2000), Der disaggregierte Regulierungsansatz der Netzökonomie, in:

Knieps, G. and G. Brunekreeft (Eds.), Zwischen Regulierung und

Wettbewerb-Netzsektoren in Deutschland, Heidelberg.

Knieps, G. (2001), Wholesale/retail pricing in telecom markets, Paper presented at the WIK Seminar on Regulatory Economics, Königswinter.

Laffont, J. and J. Tirole (2000), Competition in Telecommunications, London.

Merkt, J. (1998), Wettbewerb im Local Loop: Strukturwandel und Netzwettbewerb in Telekommunikationsortsnetzen, Baden-Baden.

Monopolkommission (2001), Wettbewerbsentwicklung bei Telekommunikations und Post 2001: Unsicherheit und Stillstand, in: 2. Sondergutachten der Monopolkommission, Bonn.

Möschel, W. (2001), Die Öffnung der Breitbandkabelnetze für den Wettbewerb: Die Sicht der Monopolkommission, Multimedia und Recht February 2001, 13-19. OECD (2001), The Development of Broadband Access in OECD Countries, Paris. 
Picot, A. and W. Burr (1996), Regulierung der Deregulierung im Telekommunikationssektor, Zeitschrift für betriebswirtschaftliche Forschung 48/ 2, 173-200.

RegTP (2001a), Ortswettbewerb 2000, Bonn.

RegTP (2002b), Tätigkeitsbericht 2000/2001, Bonn.

Shepherd, W.G. (1984), Contestability vs. Competition, American Economic Review 74/4, 572-587.

Squire Sanders, Legal Counsel Worldwide (2002), Legal Study on Part II of the Local Loop. Sectoral Inquiry, Brussels.

Wichert-Nick, D. von (1999), Wettbewerb im lokalen Telekommunikationsmarkt:

Zwischen sektorspezifischer Regulierung und allgemeinem Wettbewerbsrecht, Baden-Baden. 